\title{
AYURVEDIC MANAGEMENT OF PITYRIASIS ALBA (SIDHMA KUSTHA): A CASE STUDY
}

\author{
Gahalawat Preeti ${ }^{1 *}$ and Kumar Pankaj ${ }^{2}$ \\ ${ }^{1}$ Final Year Student, Ayujyoti Ayurvedic College and Hospital, Jodhpuria, Sirsa, Haryana, India \\ ${ }^{2}$ Assistant Professor, Department of Panchakarma, Ayujyoti Ayurvedic College and Hospital, Jodhpuria Sirsa, Haryana, \\ India
}

Received on: 19/10/20 Accepted on: 11/02/21

\author{
*Corresponding author \\ E-mail: preetimanpreet157@gmail.com
}

DOI: $10.7897 / 2277-4343.12018$

\begin{abstract}
A skin rash that sometimes begins as a large spot on the chest, abdomen, hands or back followed by pattern of smaller lesions. Pityriasis refers to hypo pigmentation of skin. Pityriasis alba have symptoms like ill-defined patches, round and oval, often with mild scaling and sometimes with mild pruritus. They are most commonly noticeable in people with darker skin type. Clinical examination shows decreased melanin production in affected areas. Pityriasis alba is commonly caused by atrophic sebaceous glands, iron deficiency anemia, low level of serum copper and sun exposure. It occurs commonly in children aged 3-16 years with $90 \%$ of occurring in children younger than 12 years. An estimated $5 \%$ of children in US may be affected. Studies have showed a higher prevalence in Egypt 18\% and Mali 20\%. There is no clear racial predominance of Pityriasis alba found. Duration of the rash is variable. According to Acharya Sushruta Sidhma Kustha is kapha pradhana vyadhi most commonly occurs in Urdhva kaya i.e., hasta, ura, mukha and lalata. Diseases start with mild kandu and result in formation of white thin patches without pain. A female patient of 24 years attended our OPD with complain of various circular, whitish, discoloured patches of irregular edges with moderate pruritis on bilateral upper limbs and neck root region anteriorly. Finally, on the basis of all sign and symptoms it was diagnosed as Sidhma Kustha. In treatment repeated Vamana karma and Virechana karma were done. Given treatment mainly pacifies kapha along with vata dosha.
\end{abstract}

Keywords: Pityriasis alba, Sidhma Kustha, Shodhana.

\section{INTRODUCTION}

Pityriasis alba is a common benign skin disorder occurring predominantly in children and adults. Pityriasis refers to its Hypo pigmentation. Pityriasis alba is characterised by ill-defined patches, round and oval, often with mild scaling and sometimes with mild pruritus. They are most commonly located on face, arms and upper trunk and are most noticeable in people with darker skin type. It is noncontagious and non-infectious diseases. Histopathology shows decreased melanin production in affected areas ${ }^{1}$. Most common cause of Pityriasis alba are atrophic sebaceous glands, iron deficiency anemia, low level of serum copper and sun exposure.

It is more common in children aged 3-16 years with $90 \%$ of occurring in children younger than 12 years. An estimated 5\% of children in US may be affected. Studies have demonstrated a higher prevalence in Egypt 18\% and Mali 20\%. There is no clear racial predominance.

On the basis of sign and symptoms Pityriasis alba is very similar to Sidhma Kustha mentioned by Acharya Sushruta in Ayurveda. Sidhma Kustha is one of the most common but miserable Twak vikara affecting all the age of population still stands as a challenge to different medical systems ${ }^{2}$. Many research works have been done on skin disorders in modern medical science, but no drug has yet been claimed to cure this skin diseases completely and prevent its recurrence. According to Acharya Sushruta Sidhma Kustha is kapha pradhana vyadhi most commonly occurs in Urdhva kaya i.e., hasta, ura, mukha and lalata ${ }^{3}$. Diseases start with mild kandu and result in formation of white thin patches without pain. Finally, on basis of all sign and symptoms it was diagnosed as Sidhma Kustha. I am delighted to let you know that this is my own case of Sidhma Kustha.

\section{MATERIAL AND METHODS}

A female patient from Sonipat, Haryana at the age of 24 years, consulted our college (Ayujyoti Ayurvedic college and hospital Jodhpuria, Sirsa, Haryana, India) physician for complain of various circular, whitish, discoloured patches of irregular edges with moderate pruritis on bilateral upper limbs and neck root region anteriorly. She consulted allopathic physicians many times but got no satisfactory results. Along with this she was also having a history of severe acne vulgaris from about 10 years. For that she consulted allopathic physicians' multiple times. In February. 2019 she was advised to take salt isotretinoin in a dose of $10 \mathrm{mg}$ twice a day for duration of 6 months. After that her acne got resolved but as isotretinoin capsule do atrophy of sebaceous glands and reduces the amount of natural oil made by skin. So as a side effect of this drug she developed dry eyes, mouth and lips. Her skin became photosensitive. After one month she developed these white patches on bilateral upper limbs and neck root region. As pityriasis alba also have aetiology of occurring by atrophic sebaceous glands, sun exposure etc. So, we may say that she developed the diseases as a side effect of isotretinoin salt. So, she switched over to Ayurvedic treatment by consulting with physician in our college hospital. She was admitted in hospital for treatment. After 2 months of treatment, she got 100\% relief in whitish patches and itching.

Study is carried out as per International conference of Harmonization-Good Clinical Practices Guidelines (ICH-GCP) or as per Declaration of Helsinki guidelines. 


\section{Physical examination}

On inspection white circular patches with irregular edges were seen on bilateral upper limbs and root of neck anteriorly.

\section{Investigations}

Table 1: Investigations

\begin{tabular}{|c|c|}
\hline Prakriti & Pittakaphaja \\
\hline Aahar Shakti & Madhyama \\
\hline Vyayama Shakti & Avara \\
\hline Samhanana & Madhyama \\
\hline Dosha & kapha \\
\hline Dhatu & Rasa dhatu \\
\hline Strotas & Rasavaha strotas, Swedovaha strotas \\
\hline Strotodusti & Sanga \\
\hline
\end{tabular}

On basis of all finding's patient was diagnosed with Sidhma Kustha (Kshudra Kustha) mentioned by Acharya Sushruta.

\section{Treatment}

\section{Shodhana Chikitsa}

Table 2: Shodhana Chikitsa

\begin{tabular}{|c|c|}
\hline Vamana Karma & $5 / 9 / 2019$ \\
\hline Virechana Karma & $20 / 9 / 2019$ \\
\hline Jalaukavacharna & $20 / 10 / 2019$ \\
\hline Raktamokshana & $22 / 10 / 2019$ \\
\hline Virechana Karma & $13 / 11 / 2019$ \\
\hline
\end{tabular}

Shamana Aushadhas

Table 3: Shamana Aushadhas

\begin{tabular}{|c|c|}
\hline${\text { Vidangarishta }+ \text { Khadirarista }^{6}+1 \text { gm Gandhaka }}^{\text {Kijayasara choorana }}$ & $30 \mathrm{ml}$ TID (after food) \\
\hline Vepa- Yavakshara + Gandhaka Bhasma + Sarshapa taila $^{7}$ & 6 gm BD mixed in food \\
\hline Anuloma- Viloma & \\
Surya Namaskara & \\
Sarvangasana & \\
\hline
\end{tabular}

\section{Vamana Karma}

Table 4: Vamana Karma

\begin{tabular}{|c|c|c|}
\hline Deepana Pachana & Panchakola Phanta $-100 \mathrm{ml}$ TID & 4 Days \\
\hline Snehapana & Tiktaka Ghrita $^{4}$ & $1^{\text {st }}$ day $-60 \mathrm{ml}$ \\
& & $2^{\text {nd }}$ day $-30 \mathrm{ml}$ \\
& & $3^{\text {rd }}$ day $-45 \mathrm{ml}$ \\
& & $4^{\text {th }}$ day $-80 \mathrm{ml}$ \\
& & $5^{\text {th }}$ day $-150 \mathrm{ml}$ \\
\hline Sarvanga Abhyanga & Bhritamarichadi taila & For 1 Day in Visrama kala \\
\hline Followed by Bashpa Sweda (Dashmoola kwatha) & Madanphala pippali ${ }^{5} 20 \mathrm{gm}$ & Vega -6 \\
& Vacha -3 gm & Pittanta vamana \\
& Yashtimadhu $-8 \mathrm{gm}$ & \\
& Saindhava $-8 \mathrm{gm}$ & \\
& Pippali $-4 \mathrm{gm}$ & \\
& Honey $-\mathrm{QS}$ & \\
\hline
\end{tabular}

After Vamana karma she got 30\% relief in patches and her Shamana Aushadha were continued. 10 days after Vamana karma, Virechana karma was planned for her.

\section{Virechana Karma}

Table 5: Virechana Karma

\begin{tabular}{|c|c|c|}
\hline Deepana Pachana & $\begin{array}{c}\text { Panchakola Phanta - 100 ml TID } \\
\text { Chitrakadi vati- 1 TID (before food) }\end{array}$ & 4 Days \\
\hline Snehapana & Mahatiktaka Ghrita & $\begin{array}{c}1^{\text {st }} \text { day }-40 \mathrm{ml} \\
2^{\text {nd }} \mathrm{day}-90 \mathrm{ml} \\
3^{\text {rd }} \text { day }-160 \mathrm{ml}\end{array}$ \\
\hline $\begin{array}{c}\text { Sarvanga Abhyanga } \\
\text { Followed by Bashpa Sweda (Dashmoola kwatha) }\end{array}$ & Bhritamarichadi taila & $\begin{array}{c}\text { For 3 Day in Visrama } \\
\text { kala }\end{array}$ \\
\hline Virechana & $\begin{array}{c}\text { Trivrit avleha } \\
\text { Drakshasava } \\
\text { Triphala 28 ashaya }\end{array}$ & $\begin{array}{c}\text { Vega }-30 \\
\text { Kaphanta Virechana }\end{array}$ \\
\hline
\end{tabular}

After that she got 50\% relief in all sign and symptoms. But she was not satisfied with results. So, after one-month Jalaukavacharna near patches and Siravedha were done. But there was no further improvement. Same Shamana aushadhas were continued during this whole period. After 15 days again Vamana was planned. 
Gahalawat Preeti and Kumar Pankaj / Int. J. Res. Ayurveda Pharm. 12 (1), 2021

\section{Vamana karma}

Table 6: Vamana Karma

\begin{tabular}{|c|c|c|}
\hline Deepana Pachana & Panchakola Phanta $-100 \mathrm{ml}$ TID & 4 Days \\
\hline Snehapana & Tiktaka Ghrita & $\begin{array}{r}1^{\text {st }} \text { day }-60 \mathrm{ml} \\
2^{\text {nd }} \text { day }-30 \mathrm{ml} \\
3^{\text {rd }} \text { day }-45 \mathrm{ml} \\
4^{\text {th }} \text { day }-80 \mathrm{ml} \\
5^{\text {th }} \text { day }-150 \mathrm{ml}\end{array}$ \\
\hline $\begin{array}{c}\text { Sarvanga Abhyanga } \\
\text { Followed by Bashpa Sweda (Dashmoola kwatha) }\end{array}$ & Bhritamarichadi taila & For 1 Day in Visrama kala \\
\hline Vamana & $\begin{array}{c}\text { Madanphala Pippali - } 20 \text { gm } \\
\text { Vacha -3 gm } \\
\text { Yashtimadhu - } 8 \text { gm } \\
\text { Saindhava - } 8 \text { gm } \\
\text { Pippali - } 4 \text { gm } \\
\text { Honey - QS } \\
\end{array}$ & $\begin{array}{c}\text { Vega }-5 \\
\text { Pittanta vamana }\end{array}$ \\
\hline
\end{tabular}

After Vamana Karma she got $100 \%$ relief in all sign and symptoms.

\section{Grading parameters}

\section{Kandu}

Table 7: Kandu

\begin{tabular}{|c|c|}
\hline 0 & No itching \\
\hline 1 & Mild itching \\
\hline 2 & Moderate itching \\
\hline 3 & Severe itching \\
\hline
\end{tabular}

\section{Sweta Varna}

Table 8: Sweta Vrana

\begin{tabular}{|c|c|}
\hline 0 & Normal skin color \\
\hline 1 & Reddish white color \\
\hline 2 & Pearly white color \\
\hline 3 & White color \\
\hline
\end{tabular}

\section{Number of Lesion}

Table 9: Number of lesions

\begin{tabular}{|l|l|}
\hline 0 & No lesion \\
\hline 1 & $1-3$ lesion \\
\hline 2 & 4-6 lesion \\
\hline 3 & $>6$ lesion \\
\hline
\end{tabular}

\section{Diameter of Lesion}

Table 10: Diameter of Lesion

\begin{tabular}{|c|c|}
\hline 0 & No lesion \\
\hline 1 & Lesion of diameter $1-2 \mathrm{~cm}$ \\
\hline 2 & Lesion with diameter $2-4 \mathrm{~cm}$ \\
\hline 3 & Lesion with diameter $5 \mathrm{~cm}$ or more \\
\hline
\end{tabular}

\section{RESULT AND DISCUSSION}

\section{Table 11: Result}

\begin{tabular}{|c|c|c|}
\hline & Before Treatment & After Treatment \\
\hline Kandu & 3 & 0 \\
\hline Sweta Vrana & 4 & 0 \\
\hline No. of Lesions & 4 & 0 \\
\hline Diameter of Lesion & 3 & $0^{9-11}$ \\
\hline
\end{tabular}

In this case of Sidhma Kustha, the main treatment procedure adopted here were Vamana and Virechana Karma. Ayurveda emphasises treatment of diseases in holistic approach particularly correcting the root cause through Samshodhana, specifically for skin diseases like Pityriasis alba; Vamana karma and Virechana karma are advised. By nature, Kustha is difficult to cure. So, it is called Dushchikitsya. But by using shodhana therapy repeatedly as mentioned by Acharya Sushruta Vamana for every 15 days, Virechana for every 30 days, Raktamokshana for every 6 months, Lepa for every 3 days; cure of diseases become easier due to removal of root cause.

Vamana Karma expels out toxins present in Rasadi dhatu and purifies dushya of skin diseases. Vamana clears channels which improves process of body nourishment. It further clears Bahya rogamarga and increases Indriya bala of Twak thus reduces severity of skin disorders. 
Virechana Karma pacifies vitiated pitta dosha and also help in eliminating vitiated kapha dosha, corrects dushit rakta dhatu, causes vatanulomana, do strotoshodhana.

Snehapana due to similarities in chemical and physiological nature in ghrita and human cell membrane intensify the penetration of Sneha into deeper tissues causing partial rejuvenation of cell, smoothening of vitiated dosha (stagnated metabolic waste). Soothed doshas will get liquified and reaches to Koshtha by Swedana.

Sarvanga abhyanga was done with Bhritamarichyadi taila which is vatakapha shamaka. Panchakola Phanta and Chitrakadi vati are Deepana, Pachana, Rochana, Anulomana and Kusthahara. Tiktaka and Mahatiktaka ghrita are tikta pradhana which helps in pitta and kapha alleviation and thus covering up lakshanas in Sidhma Kustha. Vamana karma is best therapy for vitiated kapha dosha from all over the body. Here main drug used for vamana is Madanphala Pippali. Acharya Charaka has quoted Madanphala as a best Vamaka dravya considering it as Anpayitvata. And due to its laghu, ruksha guna, ushna veerya and katu vipaka- do chardana, eliminate vitiated kapha and does not cause any adverse effect.

Virechana by Trivrit Avleha also done a marked effect on vitiated kapha as Trivrit Avleha contains Trivrit, Trijataka and Honey etc. which due to its laghu, ruksha, tikshna guna and ushna virya do kapha and pitta samshodhana. Trivrit is mentioned as sukha virechaka by Acharya Charaka. Khadirarishta mainly contains Khadira, Devdaru, Daruharidra, Triphala etc. these days due to their guna and karma are kapha and vata shamaka and do amapachana thus is Kandughna. It is mentioned as best kusthaghna dravya by Acharya Charaka. Vidangarishta mainly pacifies kapha dosha along with vata dosha and is best Krimighna as per Acharya Charaka.

\section{CONCLUSION}

All the above adapted treatment pacifies Kapha along with vata dosha because of their Guna and Karma. Hence repeated Vamana karma and Virechana Karma could be a good line of treatment with other suitable procedures in Sidhma Kustha.

\section{REFERENCES}

1. Gilver DN, Basit H, Givler A. Pityriasis Alba. 2020 Aug 14. In: Stat Pearls, Internet. Treasure Island, FL: Stat Pearls Publishing; 2020 Jan- PMID: 28613715. Available from: http://www.ncbi.nlm.nih.gov

2. Chandra S, Kumar S, Verma MS, Ghuraiya S. A clinical study on the role of Gandhaka Malahara in management of
Charakokta and Sushrutokta Type 1 Sidhma and Type 2 Sidhma Kustha; 2018 oct.30. Available from: http://www.journalijdr.com

3. Sushruta, Kusthadinidana adhyaya. In: Ayurveda Tattva Sandipika Hindi Commentary, Kaviraja Ambikadutta Shastri, Sushruta Samhita Purvardha Nidana Sthana, reprint edition. Varanasi: Chaukhambha Sanskrit Sansthan; 2018. p. 321, 5: 15.

4. Sushruta, Kusthachikitsa adhyaya. In: Ayurveda Tattva Sandipika Hindi Commentary, Kaviraja Ambikadutta Shastri, Sushruta Samhita Purvardha Chikitsa Sthana, reprint edition. Varanasi: Chaukhambha Sanskrit Sansthan; 2018. p. 63, 9:9.

5. Charaka, Madankalpa adhyaya. In: Vidyotini Hindi commentary, Pandit Kashinath Shastri, Dr. Gorakhnath Chaturvedi, Charaka Samhita Uttarardha Kalpa Sthana, reprint edition. Varanasi: Chaukhambha Bharati Academy; 2017. p. 896, 1: 13 .

6. Sharangadhara. Sharangadhara Samhita. Madhyama khanda. Aasavaristasandhanakalpana adhyaya, chapter no. 10, verse 60-65. Jiwanprada Hindi commentary. Edited by Dr. Smt. Shailajaya Srivastava. Varanasi: Chaukhambha Orientalia; 2009. p. 252.

7. Sushruta, Dravyasamgrahaniya adhyaya. In: Ayurveda Tattva Sandipika Hindi Commentary, Kaviraja Ambikadutta Shastri, Sushruta Samhita Purvardha Chikitsa Sthana, reprint edition. Varanasi: Chaukhambha Sanskrit Sansthan; 2018. p. 183-184, 38:12-13.

8. Charaka, Shayamatrivritakalpa adhyaya. In: Vidyotini Hindi commentary, Pandit Kashinath Shastri, Dr. Gorakhnath Chaturvedi, Charaka Samhita Uttarardha Kalpa Sthana, reprint edition. Varanasi: Chaukhambha Bharati Academy; 2017. p. 920,7: 23.

9. Bishnoi P, Kumar P. Role of Vyatyasa Chikitsa In Management of Greeva Stambha: A Case Study. Int J. Res. Ayurveda Pharm 2020; 11(3): 10-12 http://dxdoi.org/ $10.7897 / 2277-4343.110350$

10. Gahalawat M, Kumar P. Effect of Kareesha Pinda sweda In Vatakaphaja Gridhrasi: A Case Study. Int. J. Res. Ayurveda Pharma 2020; 11(3): 4-6 http://dxdoi.org/10.7897/22774343.110348

11. Gahalawat P, Kumar P. Ayurvedic Management of Sacrolitis: A Case Study. Int. J. Res. Ayurveda Pharma 2020; 11(3): 7-9 http://dx.doi.org/10.7897/2277-4343.110349

\section{Cite this article as:}

Gahalawat Preeti and Kumar Pankaj. Ayurvedic management of Pityriasis alba (Sidhma Kustha): A Case Study. Int. J. Res. Ayurveda Pharm. 2021;12(1):27-30 http://dx.doi.org/10.7897/ 2277-4343.12018 every effort has been taken to verify the accuracy of the content published in our Journal. IJRAP cannot accept any responsibility or liability for the site content and articles published. The views expressed in articles by our contributing authors are not necessarily those of IJRAP editor or editorial board members. 